\title{
Protected sites in the Alps with an internationally awarded natural or cultural desig- nation as of 1 January 2015 - an overview
}

\author{
Peter Strasser \\ Keywords: Alpine Convention, Alps, Biosphere Reserve, Council of Europe, Emerald Site, European Cultural Route, European \\ Diploma, European Union, Geopark, IUCN Protected Areas, National Park (IUCN Category 2), Natura 2000 site, Europa \\ Nostra Award / EU Prize for Cultural Heritage, Ramsar Protected Area, Strict Nature Reserve (IUCN Category 1a), UNESCO, \\ Wilderness Area (IUCN Category 1b), World Heritage List
}

Abstract

The former Working Group UNESCO World Heritage of the Alpine Convention was tasked by the Alpine Conference to check the possibility of applying other instruments and international programmes to enhance the awareness about sites in the Alps. Following this mandate, as of 1 January 2015, 1345 internationally designated sites, divided into 12 categories, of cultural and natural heritage in the Alps could be identified and compiled in a list. The results were analysed according to the following topics: 1) percentage of Alpine sites within the global, total scope of application of the designations (programmes and conventions), 2) agencies involved (globally and regionally active organizations), 3) number of the culture/nature sites and 4) multiple designations of an individual site.

Following an intensive revision (which led to a substantial enlargement of the list, as the initial list included 98 sites before it was augmented 14-fold), the list has been made available for the recently created WG Sustainable Tourism of the Alpine Convention as a basis of its work.

\section{Introduction}

The Working Group (WG) UNESCO World Heritage (2007-2014) (2015) of the Alpine Convention was tasked by the Alpine Conference for its (last) working period 2013-2014 to check the possibility of applying other instruments and international programmes to enhance awareness of the value of sites in the Alps. The mandate referred to the UNESCO Convention for the Safeguarding of the Intangible Cultural Heritage of 2003, to Biosphere Reserves, Geoparks, Ramsar Sites and to the European Diploma of the CoE, all of which should be considered. (see also Arbeitsgruppe UNESCO-Welterbe, Alpine Convention 2013).

This broad approach covering other programmes and conventions is partly backed by the World Heritage Committee. Paragraph 41 of the Operational Guidelines for the Implementation of the World Heritage Convention 2013 stipulates that, "the World Heritage Committee recognizes the benefits of closer coordination of its work, with other UNESCO programmes and their relevant Conventions." The advisory bodies of the World Heritage Committee - such as IUCN - also recommended in their evaluation of sites proposed for entry in the World Heritage List to "consider the potential use of alternative means of recognition of these sites through national and regional systems of protection and promotion." (IUCN 2014).

Based on the mandate, the author was asked by the members of the WG to draw up a list of all sites in the Alps with an internationally recognized designation of cultural and natural heritage.

The version presented to the WG in autumn 2014 identified 98 sites in the Alps with (at least) one of the following seven designations: World Heritage Site,
Geopark, Biosphere Reserve, Ramsar Site, CoE European Diploma, EN Prize / EU Award or CoE Cultural Routes. Following discussions with experts, the author revised the list in spring 2015 and included five additional designations of EU, CoE and IUCN: Natura 2000, Emerald Site, Strict Nature Reserve (IUCN Category 1a), Wilderness Area (IUCN Category 1b) and National Park (IUCN Category 2). However, this revision led not only to a considerable enlargement of the list (a 14-fold increase), see Table 1, but also to substantial changes in the results. The present list covers 1345 sites of the above-mentioned designations in the Alps (Table 2, Supplementary Table, online).

At the first meeting of the WG Sustainable Tourism of the Alpine Convention on 17 April 2015 in Belluno, Italy, the author offered to provide the members of the WG with this list (Sustainable tourism WG 2006). The information contained in the list could serve as basis for fulfilling the task stipulated in the mandate of the WG valorization of the cultural and natural heritage in the Alps for sustainable tourism. The substantial amendments to the list caused some delay in the submission.

\section{Overview}

Many sites in the Alps have been designated as regionally or globally important by assigning or granting those natural and / or cultural designations. In a study by ALPARC in 2013, some 400 larger protected areas (over $100 \mathrm{ha}$ ) in the Alpine area were identified. These designations are of diverse protective character and size, and they were awarded either by applying regional, national or international standards. Some of these sites hold multiple designations and titles (Table 3). 
Table 1 - International designations in the fields of nature and culture.

\begin{tabular}{|c|c|c|c|c|}
\hline Designation & Legal basis & Main objectives & Governance structure & $\begin{array}{l}\text { Area of } \\
\text { implementation }\end{array}$ \\
\hline World Heritage & World Heritage Convention 1972 & $\begin{array}{l}\text { Protection of the natural and cul- } \\
\text { tural heritage, WH List, list WH in } \\
\text { Danger, international cooperation, } \\
\text { financial assistance through the } \\
\text { World Heritage Fund }\end{array}$ & $\begin{array}{l}191 \text { State Parties to the Conven- } \\
\text { tion, meet every } 2 \text { years as General } \\
\text { Assembly } \\
\text { WH Committee ( } 21 \text { member states) } \\
\text { Secretariat: UNESCO-WHC, advisory } \\
\text { bodies (ICOMOS, IUCN, ICCROM) }\end{array}$ & Global \\
\hline Geopark & $\begin{array}{l}\text { Voluntary, non-legally binding net- } \\
\text { work of member territories (Global } \\
\text { Geoparks Network - GGN), } \\
\text { background: GGN Charter (code } \\
\text { of conduct \& best practice) }\end{array}$ & $\begin{array}{l}\text { Promotion of the significance and } \\
\text { need for protection of geological } \\
\text { heritage through engagement with } \\
\text { local communities, awareness- } \\
\text { raising on climate change }\end{array}$ & $\begin{array}{l}32 \text { participating states } \\
\text { Coordination: Global Geoparks } \\
\text { Network (GGN) } \\
\text { UNESCO provides ad hoc support to } \\
\text { national Geoparks initiatives }\end{array}$ & Global \\
\hline Biosphere Reserve & $\begin{array}{l}\text { Intergovernmental UNESCO Man } \\
\text { and Biosphere Programme (MAB), } \\
1995\end{array}$ & $\begin{array}{l}\text { Harmonized conservation } \\
\text { management of biological and } \\
\text { cultural diversity, economic and } \\
\text { social development based on local } \\
\text { community }\end{array}$ & $\begin{array}{l}\text { All } 195 \text { Member States of UNESCO's } \\
\text { International Co-ordinating Council } \\
\text { of the MAB Programme (MAB-ICC, } \\
34 \text { Member States) } \\
\text { Secretariat: UNESCO-MAB Secretariat }\end{array}$ & Global \\
\hline Ramsar Site & $\begin{array}{l}\text { Convention on Wetlands of Inter- } \\
\text { national Importance } 1971 \text { (Ramsar } \\
\text { Convention) }\end{array}$ & $\begin{array}{l}\text { Conservation and wise use of } \\
\text { wetlands through local and } \\
\text { national actions and international } \\
\text { cooperation }\end{array}$ & $\begin{array}{l}168 \text { Contracting Parties (Meeting of } \\
\text { the Conference of the Parties) } \\
\text { Standing Committee ( } 18 \text { members) } \\
\text { Secretariat hosted by IUCN }\end{array}$ & Global \\
\hline $\begin{array}{l}\text { Strict Nature Reserve } \\
\text { (IUCN Category la) }\end{array}$ & $\begin{array}{l}\text { IUCN classification of protected } \\
\text { area categories (justification in: } \\
\text { Best Practice Guideline No. 21) }\end{array}$ & $\begin{array}{l}\text { Protection of biodiversity and even- } \\
\text { tually geological/geomorphologi- } \\
\text { cal features, strict control of human } \\
\text { visits, use and impacts }\end{array}$ & Classification administered by IUCN & Global \\
\hline $\begin{array}{l}\text { Wilderness Area } \\
\text { (IUCN Category 1b) }\end{array}$ & $\begin{array}{l}\text { IUCN classification of protected } \\
\text { area categories (justification in: } \\
\text { Best Practice Guideline No. 21) }\end{array}$ & $\begin{array}{l}\text { Large unmodified or slightly modi- } \\
\text { fied areas, with little or no human } \\
\text { habitation to retain the natural } \\
\text { character and influence }\end{array}$ & Classification administered by IUCN & Global \\
\hline $\begin{array}{l}\text { National Park } \\
\text { (IUCN Category 2) }\end{array}$ & $\begin{array}{l}\text { IUCN classification of protected } \\
\text { area categories (justification in: } \\
\text { Best Practice Guideline No. 21) }\end{array}$ & $\begin{array}{l}\text { Protection of large areas with char- } \\
\text { acteristic species and ecosystems } \\
\text { and various visitor options (scien- } \\
\text { tific, educational and recreational } \\
\text { programmes) }\end{array}$ & Classification administered by IUCN & Global \\
\hline Natura 2000 & \begin{tabular}{|l|} 
Network of conservation areas on \\
the basis of 2 EU Directives: \\
Birds Directive (1979) \\
Habitats Directive (1992), dividing \\
EU-territory into nine biogeograph- \\
ic regions
\end{tabular} & $\begin{array}{l}2 \text { types of protected areas: } \\
\text { Special Areas of Conservation } \\
\text { (SACs) on the basis of Sites of } \\
\text { Community Importance (SCls) as } \\
\text { stipulated in the Habitats Directive } \\
\text { Special Protection Areas (SPAs) } \\
\text { for birds as stipulated in the Birds } \\
\text { Directive }\end{array}$ & $\begin{array}{l}\text { All } 28 \text { Member States of EU } \\
\text { SPAs selected by Member States } \\
\text { SACs selected by Member States, } \\
\text { followed by evaluation and selection } \\
\text { through EU Commission } \\
\text { Natura } 2000 \text { as the EU's contribution } \\
\text { to the Emerald Network }\end{array}$ & Regional (EU) \\
\hline Emerald Site & $\begin{array}{l}\text { Convention on the Conservation } \\
\text { of European Wildlife and Natural } \\
\text { Habitats (Berne Convention) }\end{array}$ & $\begin{array}{l}\text { Emerald Network consists of Areas } \\
\text { of Special Conservation Interest } \\
\text { (ASCls), which should ensure the } \\
\text { conservation and protection of } \\
\text { habitats and species listed under } \\
\text { Appendices I and II of the Berne } \\
\text { Convention }\end{array}$ & $\begin{array}{l}\text { Member states of the Berne Conven- } \\
\text { tion } \\
\text { Currently only sites in Switzerland } \\
\text { designated as Emerald sites } \\
\text { Emerald Network is based on the } \\
\text { same principles as Natura } 2000, \\
\text { quasi its extension to non-EU states }\end{array}$ & $\begin{array}{l}\text { Regional (CoE }+ \\
\text { North Africa) }\end{array}$ \\
\hline $\begin{array}{l}\text { CoE European } \\
\text { Diploma }\end{array}$ & $\begin{array}{l}\text { Since } 1965 \text { awarded by the } \\
\text { Committee of Ministers of CoE to } \\
\text { natural and semi-natural areas } \\
\text { and landscapes of exceptional } \\
\text { European importance }\end{array}$ & $\begin{array}{l}\text { Recognizing representative ele- } \\
\text { ments of the biological, geological } \\
\text { and/or landscape heritage of } \\
\text { exceptional European importance }\end{array}$ & $\begin{array}{l}47 \text { Member States of CoE } \\
\text { Annual Meeting of the Group of } \\
\text { Specialists on the European Diploma } \\
\text { of Protected Areas } \\
\text { Secretariat: CoE }\end{array}$ & Regional (CoE) \\
\hline EU-Prize / EN Awaro & $\begin{array}{l}\text { Winners selected by NGO Europa } \\
\text { Nostra, supported by the European } \\
\text { Commission within its Culture } \\
\text { Programme }\end{array}$ & $\begin{array}{l}\text { Recognizing and promoting best } \\
\text { practices for conservation (Cat- } \\
\text { egory 1), research (Category 2), } \\
\text { dedicated services (Category 3), } \\
\text { education, training and aware- } \\
\text { ness-raising (Category 4) }\end{array}$ & $\begin{array}{l}\text { Sites and citizens from all European } \\
\text { countries eligible in-situ assessment } \\
\text { by independent experts, judged by } \\
\text { four Heritage Awards Juries, organ- } \\
\text { ized by EN }\end{array}$ & Regional \\
\hline $\begin{array}{l}\text { CoE European } \\
\text { Cultural Route }\end{array}$ & $\begin{array}{l}\text { Enlarged Partial Agreement (EPA) } \\
\text { on Cultural Routes (CoE, 2011) }\end{array}$ & $\begin{array}{l}\text { Reinforcing the potential of cultural } \\
\text { routes for cultural cooperation, } \\
\text { sustainable development and so- } \\
\text { cial cohesion, focus on themes of } \\
\text { symbolic importance for European } \\
\text { unity, history, culture and values. } \\
\end{array}$ & $\begin{array}{l}23 \text { members of EPA } \\
\text { Governing Board of EPA } \\
\text { technical body: European Institute of } \\
\text { Cultural Routes (EICR, Luxemburg) }\end{array}$ & Regional (CoE) \\
\hline
\end{tabular}


Table 2 - Number of designated sites within and outside the Alps. *not confirmed, **approximately, not confirmed

\begin{tabular}{|c|c|c|c|c|}
\hline \multirow[t]{2}{*}{ Designation } & \multicolumn{2}{|c|}{$\begin{array}{l}\text { Number of sites as of } \\
1 \text { January } 2015\end{array}$} & \multirow[t]{2}{*}{$\begin{array}{l}\text { Share of Alpine } \\
\text { sites in \% }\end{array}$} & \multirow[t]{2}{*}{ Source } \\
\hline & Global total ${ }^{1}$ & in the Alps ${ }^{2}$ & & \\
\hline $\begin{array}{l}\text { World Heritage property } \\
\text { (cultural and natural) }\end{array}$ & 1007 & $\begin{array}{r}20^{3} \\
\text { (16 cultural } \\
+4 \text { natural) }\end{array}$ & 1.99 & World Heritage List (UNESCO 2015) \\
\hline Geopark & 111 & 11 & 9.91 & Members List of the GGN (Global Geoparks Network 2015) \\
\hline Biosphere Reserve & 631 & $10^{4}$ & 1.58 & $\begin{array}{l}\text { List of Biosphere Reserves in Europe \& North America } \\
\text { (UNESCO 2016) }\end{array}$ \\
\hline Ramsar Site & 2186 & 33 & 1.50 & List of Wetlands of International Importance (Ramsar 2016) \\
\hline $\begin{array}{l}\text { Strict Nature Reserve } \\
\text { (IUCN Categoryla) }\end{array}$ & $11100^{* *}$ & 411 & 3.70 & WDPA (Protected planet 2015) \& ALPARC Lists (ALPARC 2012) \\
\hline $\begin{array}{l}\text { Wilderness Area } \\
\text { (IUCN Category 1b) }\end{array}$ & $2940^{* *}$ & 22 & 0.75 & WDPA \& ALPARC Lists \\
\hline $\begin{array}{l}\text { National Park } \\
\text { (IUCN Category 2) }\end{array}$ & $150^{* *}$ & $13^{5}$ & 8.66 & WDPA \& ALPARC Lists \\
\hline Natura 2000 & 28943* & $779^{6}$ & 2.70 & $\begin{array}{l}\text { Commission Implementing Decision (EU) 2015/71, 3.12.2014 } \\
\text { (Official Journal of the European Union 2015) }\end{array}$ \\
\hline Emerald Site & 37 & 22 & 59,5 & List of Emerald Sites (December 2014) \\
\hline $\begin{array}{l}\text { CoE European Diploma } \\
\text { for Protected Areas }\end{array}$ & 73 & 9 & 12,3 & List of areas holding the Europe. Diploma for Protected Areas \\
\hline $\begin{array}{l}\text { EU-Prize / EN Award/ } \\
\text { Category 1, 2002-2014 }\end{array}$ & 239 & 6 & 2,51 & List of the EU-Prize/EN Awards (Europanostra 2015) \\
\hline $\begin{array}{l}\text { CoE European Cultural } \\
\text { Route }\end{array}$ & 29 & 9 & 31,03 & List of the CoE (Council of Europe 2014) Cultural Routes \\
\hline TOTAL in the Alps & & $1345^{7}$ & & \\
\hline
\end{tabular}

${ }^{1}$ This number includes the sites in the Alps

${ }^{2}$ Sites fully or partly in the Alpine region

${ }^{3}$ Each of the three serial and cross-border WH properties between two or more Contracting Parties of the Alpine Convention (Prehistoric Pile Dwellings around the Alps, Monte San Giorgio and Rhaetian Railway in the Albula / Bernina Landscapes) was counted only once.

${ }^{4}$ The cross-border Mont-Viso / Monviso Biosphere Reserve (France / Italy) was counted only once.

${ }^{5}$ Including Triglav National Park (not classified by IUCN under Category 2, only national designation as NP) and Swiss National Park (classified by IUCN under Category 1a)

${ }^{6}$ This figure includes only sites of community importance for the Alpine biogeographical region.

${ }^{7}$ see also Supplementary Table, online

Table 3 - Sites in the Alps with multiple designations.

\begin{tabular}{|c|c|c|c|c|c|}
\hline $\begin{array}{l}\text { Multiple } \\
\text { Designations }\end{array}$ & $\begin{array}{l}\text { Biosphere Reserve } \\
\text { (BR) }\end{array}$ & Geopark (GP) & $\begin{array}{l}\text { EU Prize/EN Award } \\
\text { (EU/EN) }\end{array}$ & Ramsar Site (RS) & $\begin{array}{l}\text { National Park (IUCN } \\
\text { Category 2) (NP) }\end{array}$ \\
\hline \multirow{2}{*}{$\begin{array}{l}\text { World Heritage } \\
\text { property (WH) }\end{array}$} & & $\begin{array}{l}\text { WH Sacri Monti } \\
\text { of Piedmont and } \\
\text { Lombardy = Sesia-Val } \\
\text { Grande GP }\end{array}$ & & & \multirow[t]{2}{*}{$\begin{array}{l}\text { WH The Dolo- } \\
\text { mites = Dolomiti } \\
\text { Bellunesi NP }\end{array}$} \\
\hline & & $\begin{array}{l}\text { WH Heritage of Mer- } \\
\text { cury. Almadén and } \\
\text { Idrija=Idrija GP }\end{array}$ & & & \\
\hline \multirow[b]{2}{*}{$\begin{array}{l}\text { Biosphere } \\
\text { Reserve (BR) }\end{array}$} & & & & \multirow{2}{*}{$\begin{array}{l}\text { Laubersmad-Salwidili } \\
\text { RS within Entlebuch } \\
\text { BR since } 2005\end{array}$} & \begin{tabular}{|l|} 
Svizzer NP = Val \\
Müstair BR \\
\end{tabular} \\
\hline & & & & & $\begin{array}{l}\text { Berchtesgaden } \\
\text { NP = Berchtesgaden- } \\
\text { er Land BR }\end{array}$ \\
\hline Geopark (GP) & $\begin{array}{l}\text { Parc Naturel Régional } \\
\text { du Luberon GP = Lu- } \\
\text { beron BR }\end{array}$ & & & & \\
\hline \multirow[b]{2}{*}{$\begin{array}{l}\text { CoE European } \\
\text { Diploma (ED) }\end{array}$} & Julian Alps BR $=E D$ & & \multirow{2}{*}{$\begin{array}{l}\text { ED Triglav } \\
\text { NP=EU/EN Pocar- } \\
\text { jeva Domacija, Triglav } \\
\text { NP }\end{array}$} & & \multirow[b]{2}{*}{ Les Ecrins NP } \\
\hline & $\begin{array}{l}\text { Val Müstair BR - Parc } \\
\text { Naziunal = ED }\end{array}$ & & & & \\
\hline $\begin{array}{l}\text { EU Prize/EN } \\
\text { Award (EU/EN) }\end{array}$ & $\begin{array}{l}\text { Julian Alps } \\
\text { BR= EU / EN Pocar- } \\
\text { jeva Domacija, Triglav } \\
\text { NP }\end{array}$ & & & & \\
\hline
\end{tabular}




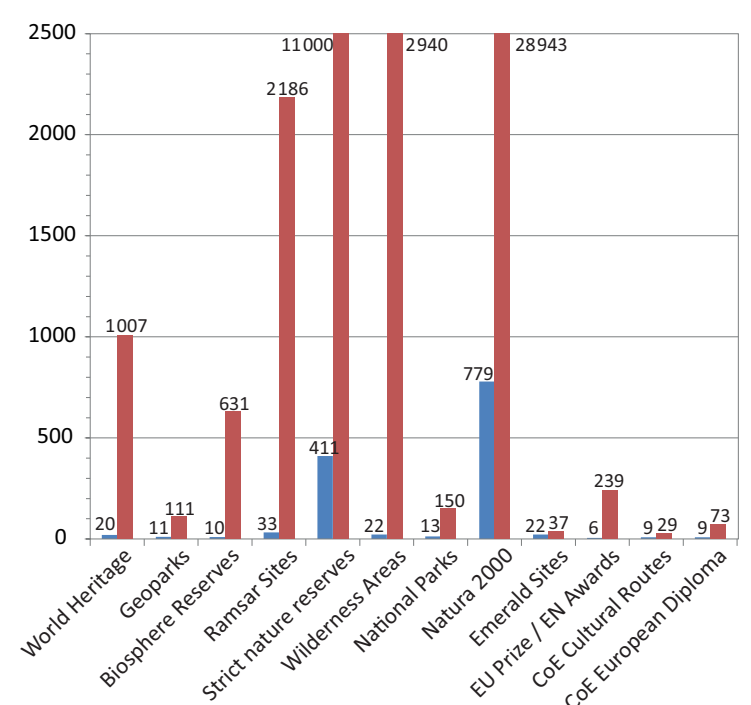

Figure 1 - Distribution of designations: number of sites worldwide (red) / Alps (blue) (1 $1^{\text {st }}$ January 2015).

The following matrix presents 12 international culture and nature designations in the Alps considered in this study. The criterion for inclusion was the international recognition of the sites by 1 January 2015 .

"In the Alps" refers to sites which are fully or partially situated within the area of the Alpine Convention as defined by the Contracting Parties.

\section{Statistics}

The statistics underlying the following analysis reveal some imbalances. Some protected areas are present in high numbers on a global scale (e.g. Strict Nature Reserve - IUCN Category 1a) or at regional level (e.g. Natura 2000 sites), whereas other categories are less often used or less frequently awarded. However, a high number of sites at global or regional level also exert an influence on the frequency of certain categories in the Alps. Of the 1345 designated sites in the Alps, 88.5\% belong to just two categories: Natura 2000 site (779 sites) and Strict Nature Reserve (IUCN Category 1a: 411 sites), Figure 1.

Natura 2000 sites and Strict Nature Reserves (IUCN Category 1a) form the majority of protected sites in the Alps; together they account for $88 \%$ of all Alpine sites (Figures 2 and 3).

\section{Analysis}

1345 designated sites of 12 categories could be identified in the Alps (see also Supplementary Table, online). The results can be analysed in terms of:

1. percentage of Alpine sites within the global total of designations,

2. agencies involved,

3. culture / nature categories and

4. multiple designations.
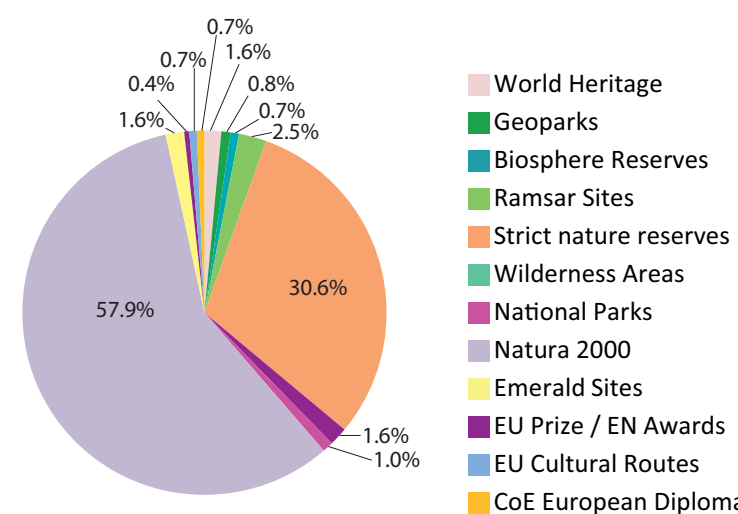

Figure 2 - Percentage of designations in the Alps (1 $1^{\text {st }}$ January 2015). $N=1345$.

Percentage of Alpine sites within the global total of designations

With regard to the percentage of Alpine sites, three groups can be identified within the 12 categories: an (exceptionally high) proportion of $59.5 \%$ of Emerald Sites of the CoE are Alpine sites, but these are located in only one country, Switzerland. Almost a third (31\%) of the Cultural Routes of the CoE cross the Alps. However, this high proportion is an estimate by the author, as the available information on the routes (Council of Europe 2014) does not always allow identifying the exact course and location of these linear sites. Geoparks and CoE European Diploma sites make up nearly 10\% and $12.3 \%$, followed by National Parks with $8.66 \%$. As these sites have clearly defined locations, these figures are exact. The third group, forming the majority, with percentages between $1.5 \%$ and $3.7 \%$, include seven different designations: Wilderness Areas (IUCN Category 1b, 0.75\%), Ramsar Sites (1.5\%), Biosphere Reserves (1.6\%), World Heritage properties (2\%), EU Prize / EN Awards (2.5\%), Natura 2000 sites (2.7\%) and Strict Nature Reserves (IUCN Category 1a, 3.7\%). Again, these figures are precise, as the exact positions of the sites are defined (Figure 4).

\section{Agencies involved}

Regarding the agencies involved, designations of the CoE make up a higher share of Alpine sites $(12.3 \%-59.5 \%)$ than those of global organizations. The higher share of $\mathrm{CoE}$ designations in the Alps stems from the CoE's regional area of responsibility, which is restricted to Europe. An exceptionally high proportion of $59.5 \%$ of the Emerald Sites are located in the Alps. The reason for this figure is the fact that Emerald Sites are currently inscribed from only one country - Switzerland.

However, at EU level, the EU Prize / EN Awards, which are also restricted to Europe, do not follow the trend set by the CoE. With an Alpine share of 2.5\%, they are rather close to the figures of global organizations, e.g. that of the Natura 2000 network with its $2.7 \%$ share in the Alps. 


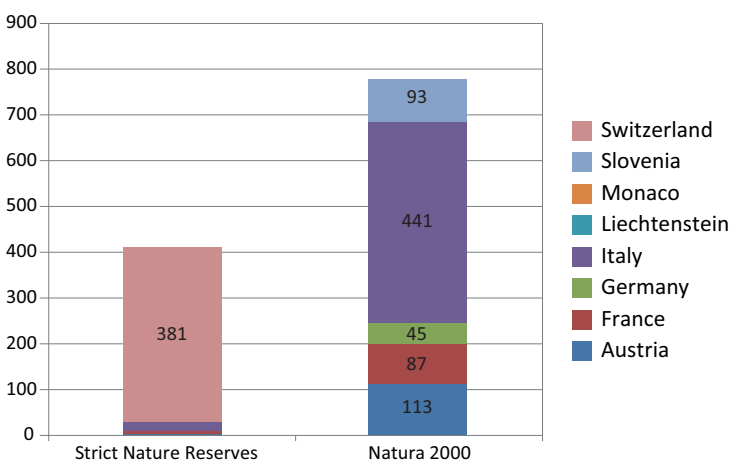

\begin{tabular}{|l|r|r|}
\hline Country & Strict Nature Reserves & Natura 2000 \\
\hline Switzerland & 381 & 0 \\
\hline Slovenia & 1 & 93 \\
\hline Monaco & 0 & 0 \\
\hline Liechtenstein & 0 & 0 \\
\hline Italy & 20 & 441 \\
\hline Germany & 0 & 45 \\
\hline France & 6 & 87 \\
\hline Austria & 3 & 113 \\
\hline
\end{tabular}

Figure 3 - Distribution of designations: Number of Strict Nature Reserves and Natura 2000 sites in the Alpine states (as of 1 January 2015).

IUCN categories present a slightly wider range: Alpine Wilderness Areas (Category 1b) make up just $0.75 \%$ of the total. Of the Strict Nature Reserves (Category 1a) $3.7 \%$ are located in the Alps, against $8.66 \%$ of the National Parks (Category 2).

Of the designations based on UNESCO's global programmes and conventions (World Heritage, Ramsar Sites, Biosphere Reserves) a strikingly low share between $1.5 \%$ and $2 \%$ is Alpine. Geoparks are an exception: although the network is global, almost $10 \%$ of the sites are located in the Alps (Figure 5).

\section{Categories culture / nature}

There is a clear dominance of natural site designations in the Alps, due in particular to the high number of Natura 2000 sites (779 sites) and Strict Nature Reserves (IUCN Category 1a, 411 sites). Of the 1345 designated sites, 98\% (1314 sites) were awarded a natural designation and only 31 sites $(2 \%)$ a cultural designation. It should be noted, however, that the World Heritage properties exert a small modifying effect on this result. Following the global structure of the World Heritage List (1007 properties: Culture / Nature / Mixed: $780 / 197 / 30$ ), the number of cultural properties in the Alps (16) is four times as high as that of natural World Heritage sites (4) there (Figure 6).

\section{Multiple Designations}

Some sites - or parts of them - have more than one designation.

One of the Geoparks is a Biosphere Reserve (Luberon, France), two are World Heritage properties (Sacri Monti of Piedmont, Italy and Idrija, Slovenia). Two Biosphere Reserves - apart from the already men-

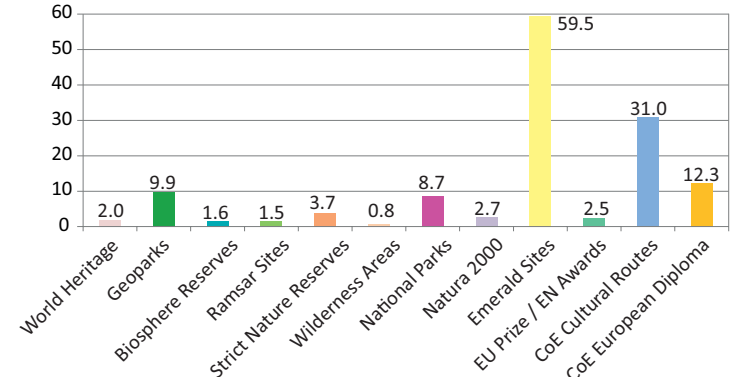

Figure 4 - Share of Alpine sites of the global total in \% (as of 1 January 2015).

tioned Geopark Luberon in France - also received the European Diploma of the CoE (Julian Alps, Slovenia and Val Müstair, Switzerland). Several National Parks also received the European Diploma of the CoE (including Les Ecrins NP, which is protected under seven different designations, apart from National Park, also Site of Community Importance, Special Protection Area, Biological Protection Order, National Nature Reserve and Forest Biological Reserve). Moreover, National Parks also became World Heritage properties (e. g. Dolomiti Bellunesi NP $=$ The Dolomites WH) or Biosphere Reserves (e.g. Svizzer NP = Val Müstair $\mathrm{BR}$, Berchtesgaden NP = Berchtesgadener Land BR). Julien Alps BR was also awarded the EU Prize / EN Award. Entlebuch BR, Switzerland, includes Laubersmad-Salwidili Ramsar Site. In Italy, eight Strict Nature Reserves (IUCN Category 1a) form part of the WH property The Dolomites / Dolomiti Bellunesi NP (Table 3).

One can assume that some of the 779 Natura 2000 sites and 411 Strict Nature Reserves in the Alps have also got other designations.

\section{Conclusions}

International actors have awarded many labels for the protection of the natural and cultural heritage in the Alps. As a result, the Alps are an intensively protected area - especially the natural areas. However, the labels also serve as tourist attractions and as assets for promoting the tourism destinations.

However, it is not yet clear how the labels contribute to results other than just protecting nature. (The emphasis here is on nature, as only $2 \%$ of the designations in the Alps have a background in cultural heritage).

Therefore several questions arise with regard to the Alpine labelling:

First, the impact of labels on tourism requires deeper research. Do labels stimulate more tourism or are they an obstacle for touristic development? The question of how the labels are used as touristic resource is currently subject of the WG on Sustainable Tourism of the Alpine Convention, which was set up by the XIII. Alpine Conference on 21 November 2014 in Turin. As one of its tasks the WG has worked since 


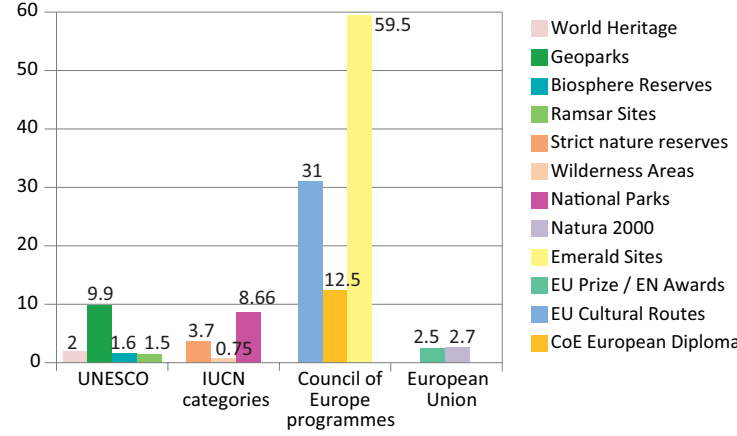

Figure 5 - Share of Alpine sites based on agencies and programmes involved, in \% (as of 1 January 2015).

early 2015 on the valorization of the natural and cultural heritage of the Alps (Alpine Convention 2006).

Moreover, $98 \%$ of all labels refer to the protection of the natural heritage, while the protection of the cultural heritage plays a minor role. We have to ask if there is no Alpine cultural heritage worth protecting through international labels or if no suitable international cultural labels for the Alps are available.

Finally, the influence of nature labels on the protection of cultural elements - like cultural heritage - deserves closer investigation. Most of the nature labels also cover areas of human land use. These Alpine cultural landscapes enjoy a high protective status through the Alpine Convention (1991, Art. 3, 4, 8). However, protection instruments provided through cultural property and cultural heritage protection measures are inadequate to ensure an overall protection regime. The protection of cultural landscapes cannot be achieved by putting the areas under a glass cover - which would result in Alpine open air museums. A broad set of measures is necessary to maintain the status of the cultural landscapes as stipulated by the regulations of the Alpine Convention. It should be analysed if and how international designations, for instance, Biosphere Reserve, can contribute to the overall protection of cultural landscapes in the Alps.

In this context the question should be raised if these labels have the capacity to contribute to a sustainable development in the Alps. Geographer Werner Bätzing identified a possible scenario with regard the future of the Alps, which he located somewhere between wilderness and amusement park (Bätzing 2015). What is the effect of these international designations? Do they cause wilderness or do they turn the Alps in amusement parks?

\section{Abbreviations}

$\begin{array}{ll}\text { ALPARC } & \begin{array}{l}\text { Alpine Network of Protected Are- } \\ \text { as Association, Chambery (France) }\end{array} \\ \text { C } & \text { Culture } \\ \text { CoE } & \text { Council of Europe } \\ \text { GGN } & \text { Global Geoparks Network } \\ \text { EN } & \text { Europa Nostra }\end{array}$

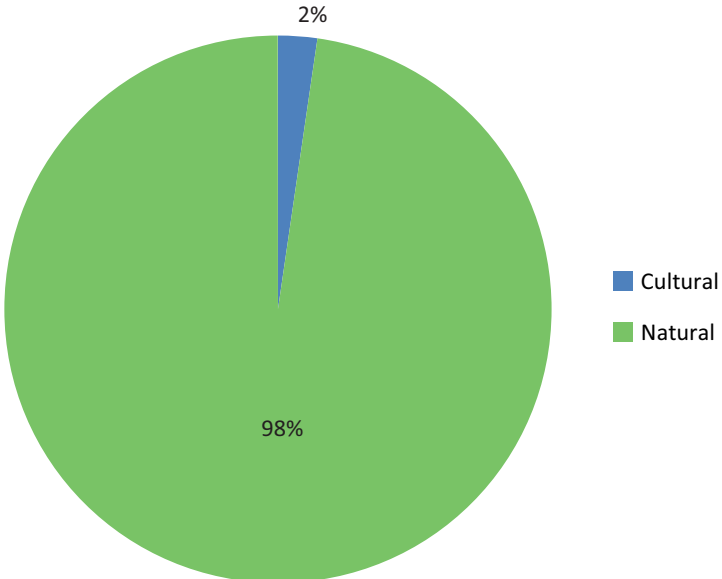

Figure 6-Number and share of cultural and natural designations in the Alps (as of 1 January 2015). $N=1345$.

\begin{tabular}{|c|c|}
\hline EU & European Union \\
\hline ICOMOS & $\begin{array}{l}\text { International Council on Monu- } \\
\text { ments and Sites }\end{array}$ \\
\hline IFP & $\begin{array}{l}\text { Inventaire des paysages, sites et } \\
\text { monuments naturels d'importance } \\
\text { nationale (Switzerland) }\end{array}$ \\
\hline IUCN & World Conservation Union \\
\hline MAB & Man and Biosphere Programme \\
\hline $\mathrm{N}$ & Nature \\
\hline NP & National Park \\
\hline NSG & Naturschutzgebiet \\
\hline UNESCO & $\begin{array}{l}\text { United Nations Educational, Scien- } \\
\text { tific and Cultural Organisation }\end{array}$ \\
\hline DPA & $\begin{array}{l}\text { World Database on Protected Ar- } \\
\text { eas }\end{array}$ \\
\hline & Working Group \\
\hline $\mathrm{H}$ & World Heritage \\
\hline
\end{tabular}

\section{References}

Alparc 2012. Discover the Alpine Protected Areas. Available at http://www.alparc.org/the-protected-areas/discover-the-apa

Alpine Convention 1991. Protocol on the implementation of the 1991 Alpine Convention in the field of mountain farming Mountain Farming Protocol Available at: http://www.alpconv.org/en/convention/protocols/Documents/MountainfarmingProtocolEN.pdf

Alpine Convention 2010. Framework Convention: 21-40. Available at: http://www.alpconv.org/en/convention/framework/Documents/Framework_en.pdf

Alpine Convention 2013. Arbeitsgruppe UNESCO-Welterbe. Available at: http://www.alpconv. org/de/organization/groups/past/WGUNESCO/ Documents/mandate2013-2014_UNESCO_de.pdf

Alpine Convention 2006. Sustainable tourism working group. Available at: http:/ /www.alpconv.org/ en/organization/groups/tourism/default.html (access 30.5.2015) 
Alpine Convention 2015. Working Group UNESCO World Heritage. Available at: http://www. alpconv.org/EN/ORGANIZATION/GROUPS / PAST/WGUNESCO/default.html (30.5.2015)

Bätzing, W. 2015. Zwischen Wildnis und Freizeitpark. Eine Streitschrift zur Zukunft der Alpen. Zürich.

Council of Europe 2014. Culture, Heritage and Diversity. Available at: http://www.coe.int/t/dg4/ cultureheritage/culture/routes/default_en.asp\#

Eropanostra 2015. EU Prize for cultural heritage / Europa nostra awards. Available at: http://www. europanostra.org/heritage-awards/

Global Geoparks Network 2015. Members list. Available at: http://www.globalgeopark.org/aboutGGN/list/index.htm

IUCN 2014. Evaluations of Nominations of Natural and Mixed Properties to the World Heritage List. IUCN Report for the World Heritage Committee, 38th Session Doha, Qatar, 15-25 June 2014: 43-51.

Official Journal of the European Union 2015. Commission implementing decision (EU) 2015/71. of 3 December 2014 adopting an eighth update of the list of sites of Community importance for the Alpine biogeographical region (notified under document C(2014) 9082). Available at: http:/ / eur-lex.europa.eu/ legal-content/EN/TXT/HTML/?uri=CELEX:3201 5D0071\&from $=\mathrm{EN}$

Protected Planet 2015. Available at: http://www. protectedplanet.net/

Ramsar 2016. The list of wetlands of international importance. Available at: http://www.ramsar.org/ sites/default/files/documents/library/sitelist_0.pdf (accessed: 20/04/2016)

UNESCO 2015. World Heritage List. Available at: http:/ /whc.unesco.org/en/list/

UNESCO 2016. Ecological Sciences for Sustainable Development. Available at: http://www.unesco. org/new/en/natural-sciences/environment/ecological-sciences/biosphere-reserves/europe-north-america/

Printed resources

All URL-links were verified on 30/05/2015

Alpine Convention 2008. Administrative Units of the Alpine Convention. Available at: http://www.alpconv.org/en/organization/parties/Documents/Administrative_Units_AC.pdf

Alpine Convention 2013. Mandat der Arbeitsgruppe „UNESCO Welterbe“ für den Zeitraum 20132014. Available at: http://www.alpconv.org/de/organization/groups/past/WGUNESCO/Documents/ mandate2013-2014_UNESCO_de.pdf

Deguignet, M., D. Juffe-Bignoli, J. Harrison, B. MacSharry, N. Burgess \& N. Kingston 2014. United Nations List of Protected Areas. UNEP-WCMC. Available at: http://unep-wcmc.org/system/dataset_ file_fields/files/000/000/263/original/2014_UN_ List_of_Protected_Areas_EN_web.PDF?1415613322
Dudley, N. 2014. Guidelines for Applying Protected Area Management Categories. Available at: http:// cmsdata.iucn.org/downloads/iucn_assignment_1.pdf

\section{Databases \& Lists}

ALPARC: Protected Areas Listing. Available at: http://www.alparc.org/the-protected-areas/discoverthe-apa

CoE: List of areas holding the European Diploma for Protected Areas Available at: http://www. coe.int/t/dg4/cultureheritage/nature/diploma/ Documents/List_of_Diploma_2014.pdf

UNESCO: List of Biosphere Reserves in Europe \& North America. Available at: http://www.unesco.org/ new/en/natural-sciences/environment/ecologicalsciences/biosphere-reserves/europe-north-america/

CoE: List of the Cultural Routes of the CoE. Available at: http://www.coe.int/t/dg4/cultureheritage/ culture/routes/default_en.asp

EN: List of the EU-Prize / EN Awards . Available at: http://www.europanostra.org/heritage-awards/

GGN: Members List of the GGN. Available at: http://www.globalgeopark.org/aboutGGN/list/index.htm

Ramsar Convention Secretariat: The List of Wetlands of International Importance. Available at: http:/ /www.ramsar.org/sites/default/files/documents/library/sitelist_0.pdf

UNEP/IUCN: World Database on protected Areas (WDPA). UNEP-WCMC: Cambridge, UK 2014 Available at: www.protectedplanet.net

UNESCO: World Heritage List. Available at: http://whc.unesco.org/en/list/

EU: Commission implementing Decision (EU) 2015/71 of 3 December 2014, adopting an eight update of the list of sites of Community importance for the Alpine biogeographical region (notified under document C(2014) 9082); in: Official Journal of the European Union, L 18/328 (EN), 23.1.2015. Available at: http://eur-lex.europa.eu/legal-content/EN/ TXT/HTML/?uri=CELEX:32015D0071\&from= EN (Natura 2000 sites for the Alpine biogeographical region

CoE: List of Emerald sites (2014) Available at: https://wcd.coe.int/com.instranet. InstraServlet? command $=$ com .instranet. . $m$ dBlobGet \&InstranetImage $=2680894 \&$ SecMode $=1 \&$ DocId $=2$ $232878 \&$ Usage $=2$

\section{Legal Instruments}

Directive 2009/147/EC of the European Parliament and the Council of 30 November 2009 on the conservation of wild birds (Birds Directive). Available at: http://eur-lex.europa.eu/legal-content/ EN/TXT/HTML/?uri=CELEX:32009L0147\&from $=\mathrm{EN}$

Convention on Wetlands of International Importance, especially as Waterfowl Habitat (Ramsar 
Convention), Ramsar 1971. Available at: http://www. ramsar.org/

Convention concerning the Protection of the World Cultural and Natural Heritage (World Heritage Convention) 1972 Available at: http://whc.unesco. org/en/conventiontext/

Convention on the Conservation of European Wildlife and Natural Habitats (Berne Convention) 1979. Available at: http://conventions.coe.int/Treaty/ en/Treaties/Html/104.htm

Council Directive 92/43/EEC of 21 May 1992 on the conservation of natural habitats and of wild fauna and flora (Habitat Directive)(in its consolidated, amended version of 1.1.2007). Available at: http://eur-lex.europa.eu/legal-content/ EN/TXT/HTML/?uri=CELEX:01992L004320070101\&from $=$ EN

Commission implementing Decision (EU) 2015/71 of 3 December 2014, adopting an eight update of the list of sites of Community importance for the
Alpine biogeographical region (notified under document C(2014) 9082); in: Official Journal of the European Union, L 18/328 (EN), 23.1.2015. Available at: http:/ / eur-lex.europa.eu/legal-content/EN/TXT/ HTML/?uri=CELEX:32015D0071\&from $=\mathrm{EN}$

\section{Author}

\section{Peter Strasser}

holds degrees in Law and in European Ethnology, worked at UNESCO on World Heritage, since 2012 at Danube University Krems, Head of the Zentrum für Kulturgüterschutz, numerous publications and presentations, member of the Alpine Convention Working Groups Sustainable Tourism and UNESCO World Heritage. Center for Architectural Heritage and Infrastructure, Department for Building and Environment, Danube-University Krems, Dr.-Karl-Dorrek-Str. 30，3500 Krems, Austria. E-mail: peter.strasser@donau-uni.ac.at 